Www.jmscr.igmpublication.org

Index Copernicus Value: 79.54

ISSN (e)-2347-176x ISSN (p) 2455-0450

crossrefDOI: https://dx.doi.org/10.18535/jmscr/v7i2.169

\title{
A Study of Histomorphological Prognotic Factors and Hormone Receptor Status in Therapeutic Decision Making in a Case of Carcinoma Breast
}

\author{
Authors \\ Dr S.J. Bhosale ${ }^{1}$, Dr Rajath Rakshit.R ${ }^{2}$ \\ ${ }^{1}$ P.G.Guide, ${ }^{2}$ PG Student
}

\begin{abstract}
Background and Introduction: Carcinoma breast is the most common cause of malignancy related mortality in developed countries in our country it is the second most common malignancy. Hormones such as estrogen,progesterone play a vital role in functioning and regulation of epithelial lining of the breast and endometrium. Estrogen and progesterone receptor status is a very important predictive marker in prognosis of the malignancy.

Aims and Objective: To study the histomorphological prognostic factors such as, tumorsize, histological type number of positive axillary lymph nodes, histological grading and correlate with ER/PR status and their role in systemic therapy decision making.

Materials and Method: The study included 110 patients who were admitted with diagnosis of carcinoma breast in surgical wards of Krishna hospital, their histomorphological prognostic factors were studied by histopathological examination and ER/PR status studied by immunohistochemistry and correlated, staging was done for the therapeutic decision making. This study was done over the period from October 2016 to June 2018.

Results: Patients with low Grade tumors (I and II),smaller tumor size, less positive axillary lymph nodes and showed ER/PR positive status. Age was an important factor, ER/PR status was more negative in younger age group, Poorly differentiated tumors (Grade III) showed ER/PR negative status irrespective of the age.

Staging of the tumor was done in order to facilitate the theraptic decision making, out of which majority of patients(50.00\%) would benefit only from hormonal therapy,(40.00\%) would need a combination a of hormonal and chemotherapy,(9.00\%) of patients would benefit only from chemotherapy.

Conclusion: Patients with both ER/PR positive status showed better grade, less aggressive, fewer positive lymph nodes and showed better prognosis to hormonal therapy as compared to patients with ER/PR negative status.

Hence a combination of histopathological and immunohistochemistry studies provides a valuable predictive tool for the prognosis of the patient with carcinoma breast.
\end{abstract}

\section{Introduction}

Carcinoma breast is the most common cancer in women in developed countries. In India, Breast Cancer is second to cancer of the cervix among women. ${ }^{1}$ It is grossly estimated that approximately 80,000 cases occur annually; the age adjusted incidence rates varying between 16 to $25 / 100,000$ population. $^{2}$ 
In Asian countries the peak age for breast malignancy is between 40 and 50 years, whereas the peak age in western countries is between 60 and 70 years. In India, a large proportion of patients have higher grade of tumors and more hormone receptors negative tumors than compared to the western population. ${ }^{3}$

Estrogenreceptor (ER), Progesterone receptor (PR) and Human epidermal growth factor (HER2/neu) immunostaining is very useful tool for prognosis and for treatment point of view. Determination of ER, PR status on biopsy specimen prior to therapeutic intervention is advocated as a standard clinical practice. ${ }^{1}$

Only about half $(50 \%)$ of patients with early breast cancer are treated and cured by local surgical excision alone. Therefore, it is vital to identify the set of patients in whom the malignancy is destined to recur and which patients are likely to benefit from systemic chemotherapy. ${ }^{4}$ Systemic adjuvant chemotherapies that are designed to eradicate microscopic tumor deposits/ tumor emboli that may have metastasized/ infiltrated from the primary breast cancer have been demonstrated to increase ${ }^{4}$ women's chance of long term survival.

The selection of systemic adjuvant therapy is based on prognostic and predictive markers. A predictive marker gives information about a patient's response to treatment, while a prognostic marker gives us an idea about the overall survival of the patient.

Apart from being a predictive marker, hormone receptors have their role in selecting patients for targeted therapy and can be looked upon as a promising prognostic marker too.

\section{Results}

The study was done on patients coming to the Breast Clinic of Department of Surgery and Krishna Hospital from December 2016 to June 2018. Around 110 patients with breast carcinoma detected by either FNAC/True cut biopsy not treated with neoadjuvant therapy.
Table 1: Shows the age distribution among the carcinoma breast patients

\begin{tabular}{|l|c|}
\hline Age & No. of patients \\
\hline $30-35$ yrs & 10 \\
\hline $36-40$ yrs & 12 \\
\hline $41-45 y r s$ & 16 \\
\hline $46-50 y r s$ & 19 \\
\hline $51-55 y r s$ & 14 \\
\hline $56-60 y r s$ & 15 \\
\hline $61-65 y r s$ & 10 \\
\hline $66-70 y r s$ & 10 \\
\hline$>70$ & 4 \\
\hline Total & 110 \\
\hline
\end{tabular}

The maximum number of patients was between 46 - 50 years i.e, 19 (17.27\%),

Other age groups were

$41-45$ years $(14.55 \%)$,

$56-60$ years $(13.64 \%)$,

$51-55$ years $(12.73 \%)$,

$36-40$ years $(10.91 \%)$,

then $9.09 \%$ from age groups $30-35$ years, $61-65$ years and $66-70$ years each.

More than 70 years patients were $3.64 \%$.

Table 2: Age of the patient and ER and PR status when compared

\begin{tabular}{|l|c|c|c|}
\hline $\begin{array}{l}\text { Age of } \\
\text { patients }\end{array}$ & $\begin{array}{l}\text { Estrogen } \\
\text { receptor } \\
\text { Positive }\end{array}$ & $\begin{array}{l}\text { Estrogen } \\
\text { receptor } \\
\text { negative }\end{array}$ & Total \\
\hline 30-35 yrs & 2 & 8 & 10 \\
\hline 36-40 yrs & 1 & 11 & 12 \\
\hline $41-45 y r s$ & 5 & 11 & 16 \\
\hline $46-50 y r s$ & 8 & 11 & 19 \\
\hline $51-55 y r s$ & 12 & 2 & 14 \\
\hline $56-60 y r s$ & 14 & 1 & 15 \\
\hline $61-65 y r s$ & 10 & 0 & 10 \\
\hline $66-70 y r s$ & 9 & 1 & 10 \\
\hline$>70$ & 4 & 0 & 4 \\
\hline Total & 65 & 45 & 110 \\
\hline
\end{tabular}

When we compared age groups of the patients and estrogen receptor status which is highly significant $(\mathrm{p}<0.0001)$.

The patients in younger age group had HIGHER ER AND PR NEGATIVE status compared to older age patients. 
Table 8: Tumor size and Estrogen receptor and progesterone receptor

\begin{tabular}{|l|c|c|}
\hline Tumor size & receptor positive & receptor negative \\
\hline$<2 \mathrm{cms}$ & 11 & 2 \\
\hline $2-5 \mathrm{cms}$ & 49 & 23 \\
\hline$>5 \mathrm{cms}$ & 4 & 21 \\
\hline
\end{tabular}

In our study, there is highly significant association was seen when the tumor size and ER STATUS were correlated $(\mathrm{p}<0.0001)$. The patient's ER and PR STATUS IS MORE NEGATIVE with greater tumor size.

Table 10: Lymph node number and Estrogen and progesterone receptors

\begin{tabular}{|l|c|c|}
\hline $\begin{array}{l}\text { Lymph node } \\
\text { number }\end{array}$ & $\begin{array}{c}\text { receptor } \\
\text { positive }\end{array}$ & $\begin{array}{c}\text { receptor } \\
\text { negative }\end{array}$ \\
\hline$<4$ & 62 & 26 \\
\hline $4-10$ & 2 & 20 \\
\hline$>10$ & 0 & 0 \\
\hline
\end{tabular}

When the lymph node status is compared with the ER STATUS is highly significant $(p<0.0001)$. The ER and PR STATUS IS MORE POSITIVE with lesser lymph node involvement.

Table 12: Tumor grade and Estrogen AND progesterone status

\begin{tabular}{|l|c|c|}
\hline Tumor grade & $\begin{array}{c}\text { receptor } \\
\text { Positive }\end{array}$ & $\begin{array}{c}\text { receptor } \\
\text { negative }\end{array}$ \\
\hline Grade I & 30 & $\mathbf{4}$ \\
\hline Grade II & 26 & $\mathbf{1 2}$ \\
\hline Grade III & 8 & $\mathbf{3 0}$ \\
\hline $\mathrm{P}<0.0001$ & \multicolumn{2}{|l|}{} \\
\hline
\end{tabular}

There is highly significant association between the tumor grade and ER STATUS ( $p<0.0001$ )on their comparison. ER AND PR STATUS IS INCREASINGLY NEGATIVE with higher tumor grade.

Table 14: Tumor type

\begin{tabular}{|c|c|c|}
\hline Tumor type & Number & Percentage \\
\hline IBC-NST & 86 & $78.18 \%$ \\
\hline Medullary Carcinoma & 15 & $13.64 \%$ \\
\hline Mucinous carcinoma & 7 & $6.36 \%$ \\
\hline Neuroendocrine carcinoma & 2 & $1.82 \%$ \\
\hline Total & 110 & $100 \%$ \\
\hline $\begin{array}{l}\text { Most common type of } \\
(78.18 \%) \text {, followed by } \\
(13.64 \%) .\end{array}$ & $\begin{array}{l}\text { tumor } \\
\text { medulla }\end{array}$ & $\begin{array}{l}\text { IBC-NST } \\
\text { carcinom }\end{array}$ \\
\hline
\end{tabular}

Table 15: Staging

\begin{tabular}{|l|c|c|}
\hline Stage & Number & Percentage \\
\hline IA & 12 & $10.90 \%$ \\
\hline IB & 8 & $7.27 \%$ \\
\hline IIA & 27 & $24.54 \%$ \\
\hline IIB & 33 & $30.00 \%$ \\
\hline IIIA & 30 & $27.27 \%$ \\
\hline TOTAL & 110 & $100 \%$ \\
\hline
\end{tabular}

Staging was done as per AJCC cancer staging manual. $^{22}$

Most common stage of carcinoma breast in this study was found to be stage IIB (30.00\%). Followed by IIIA (27.27\%).

Table 16: Therapeutic Decision

\begin{tabular}{|l|c|c|}
\hline Therapy Required & Number & Percentage \\
\hline Hormonal Therapy & 56 & $50.90 \%$ \\
\hline Chemotherapy & 45 & $40.90 \%$ \\
\hline Hormonal + Chemotherapy & 9 & $8.18 \%$ \\
\hline Total & 110 & $100 \%$ \\
\hline
\end{tabular}

\section{Discussion}

Breast carcinoma is a clinically and pathologically heterogeneous disease. ${ }^{5}$ various prognostic factors partake in breast carcinoma. These include age, stage, tumor size, type of tumor, nuclear and histological grade, axillary lymph node metastasis, hormone receptor status such as ER, $\mathrm{PR}^{6,14}$ Newer prognostic factors and predictors of response to therapy have come to distinguish subgroups with different biological behaviour that otherwise appear homogenous according to classic pathological and clinical criteria. IHC helps to determine the receptor status at the individual cell level, accommodating the problem of tissue heterogeneity within the tumor. ${ }^{7}$ IHC technique is relatively simple, inexpensive, and familiar to most laboratories, and results in a permanent glass slide. $^{5}$

The study of Estrogen receptor (ER), Progesterone receptor (PR) expressions in cases of breast cancer was done in our institute. Total 110 cases of breast cancer were obtained within a period of December 2016 to June 2018, which was hospital based, cross sectional study. ER, PR receptors were correlated individually with each of the prognostic factors like age, menopausal status, parity, tumor size, histological grade, axillary lymph node metastasis. 


\section{Hormone receptors and age}

Table 17: Correlation of Estrogen receptor (ER) and progesterone receptor (PR) positive status with age by various authors

\begin{tabular}{|c|c|c|c|c|c|c|}
\hline Authors & $\begin{array}{l}21-30 \\
\text { years }\end{array}$ & $\begin{array}{l}31-40 \\
\text { years }\end{array}$ & $\begin{array}{l}\text { 41- } 50 \\
\text { years }\end{array}$ & $\begin{array}{l}51-60 \\
\text { Years }\end{array}$ & $\begin{array}{l}\text { 61- 70 } \\
\text { Years }\end{array}$ & $\begin{array}{l}71-80 \\
\text { Years }\end{array}$ \\
\hline $\begin{array}{l}\text { Present } \\
\text { study }\end{array}$ & - & $\begin{array}{c}3 / 22 \\
13.63 \%\end{array}$ & $\begin{array}{c}13 / 35 \\
37.14 \%\end{array}$ & $\begin{array}{c}26 / 29 \\
89.65 \%\end{array}$ & $\begin{array}{l}19 / 20 \\
95 \%\end{array}$ & $\begin{array}{c}4 / 4 \\
00 \%\end{array}$ \\
\hline $\begin{array}{lr}\text { De et } & \text { al } \\
(2015)^{9} & \end{array}$ & $\begin{array}{c}1 / 2 \\
50 \%\end{array}$ & $\begin{array}{c}2 / 4 \\
50 \%\end{array}$ & $\begin{array}{l}5 / 11 \\
45 \%\end{array}$ & $\begin{array}{c}3 / 8 \\
37.5 \%\end{array}$ & $\begin{array}{c}4 / 5 \\
80 \%\end{array}$ & - \\
\hline $\begin{array}{l}\text { Al - } \\
\text { Nuaimy et } \\
\text { al }(2015)^{23}\end{array}$ & $\begin{array}{c}1 / 3 \\
33.3 \%\end{array}$ & $\begin{array}{l}11 / 20 \\
55 \%\end{array}$ & $\begin{array}{l}26 / 47 \\
55.3 \%\end{array}$ & $\begin{array}{l}28 / 37 \\
75.6 \%\end{array}$ & $\begin{array}{l}13 / 17 \\
76.4 \%\end{array}$ & $\begin{array}{c}2 / 4 \\
50 \%\end{array}$ \\
\hline $\begin{array}{l}\text { Chua et al } \\
(1985)^{19}\end{array}$ & - & $\begin{array}{l}16 / 28 \\
(57 \%)\end{array}$ & $\begin{array}{l}16 / 28 \\
(57 \%)\end{array}$ & $\begin{array}{c}8 / 11 \\
(73 \%)\end{array}$ & $\begin{array}{l}10 / 11 \\
(91 \%)\end{array}$ & $\begin{array}{l}10 / 11 \\
(91 \%)\end{array}$ \\
\hline
\end{tabular}

Maximum numbers of cases were in the age group of 41-50 yrs.

In contrast to the present study, a study done by Taucher et $\mathrm{al}^{24}$ on western population found that maximum number of breast cancer patients were above the age of 50 years $(72.5 \%)$.

Present study showed increased ER and PR receptor positivity with increasing age and it was statistically significant. $(\mathrm{p}=<0.0001)$

Our study is in similar with other studies which also found that ER/PR POSITIVTY increases with age, postmenopausal women with higher levels of ER/PR POSITIVE status. ${ }^{8,9,23,25}$

Chua et $\mathrm{al}^{19}$ showed the relationship of patient's age and ER status. They found that the patient < 50 years had a lower percentage of positive ER status $(57 \%)$ than the group of patients older than 60 (91\%). The difference was statistically significant $(\mathrm{p}=0.045)$ and this difference was related to patients menopausal status.

A study done by Lesser et $\mathrm{al}^{7}$ found a significant relationship between age and menopausal status. The mean age of ER positive tumors was 58.9 years which was higher than ER negative tumors having mean age of 53.7 years.

A study by Al-Nuaimy et $\mathrm{al}^{23}$, mean age of patients with ER and PR expression was $57.4 \%$ as opposed to 45.7 years among patients lacking hormonal expression $(\mathrm{p}=0.002)$. Similarly, $53.1 \%$ of patients 50 years or older were ER and PR positive as opposed to $31.9 \%$ of patients less than 50 years old : this difference was statistically significant $(\mathrm{p}=0.008)$.

\section{Hormone receptors and tumor size}

Table 18: Correlation of estrogen receptor (ER) and progesterone receptor (PR) positive status with tumor size by various authors

\begin{tabular}{|l|c|c|c|}
\hline \multirow{2}{*}{ Authors } & \multicolumn{3}{|c|}{ Tumor Size } \\
\cline { 2 - 4 } & $<\mathbf{2 ~ c m s}$ & $\mathbf{2 - 5} \mathbf{~ c m s}$ & $>\mathbf{5 c m s}$ \\
\hline Present study & $11 / 13$ & $49 / 72$ & $4 / 25$ \\
& $(84.61 \%)$ & $(68.05 \%)$ & $(16 \%)$ \\
\hline $\begin{array}{l}\text { Al- Nuaimy } \\
\text { et al (2015) }\end{array}$ & $9 / 17$ & $63 / 93$ & $9 / 18$ \\
\hline Gulam et al & $(52.9 \%)$ & $(67.7 \%)$ & $(50 \%)$ \\
(2012) $^{\mathbf{1 3}}$ & $(65 \%)$ & $(62.9 \%)$ & $(47.4 \%)$ \\
\hline $\begin{array}{l}\text { Dutta et al } \\
\mathbf{( 2 0 0 8 )}^{\mathbf{1 1}}\end{array}$ & $2 / 7$ & $18 / 55$ & $5 / 13$ \\
& $(28.4 \%)$ & $(32.7 \%)$ & $(38.4 \%)$ \\
\hline
\end{tabular}

In the present study, cases having tumor size < $2 \mathrm{cms}$ were $13(11.81 \%)$ followed by tumor size > $5 \mathrm{cms}-25$ cases $(22.72 \%)$. Most cases were found in with tumor size in between $2-5 \mathrm{cms}-72$ cases $(65.45 \%)$ which contrasts with findings observed by Western studies. A study done by Taucher et $\mathrm{al}^{24}$ on western population found most of the tumors were smaller than $2 \mathrm{~cm}(59.9 \%)$.

In this study there is high statistical significance when correlating the tumor size and hormone receptor positivity. $(\mathrm{p}=<0001)$ i.e, estrogen and progesterone negativity increase with increase in tumor size.

Similar to the present study, few other studies ${ }^{12}$, $23,13,15,26$ have found similar results.

Significant association between PR positivity and small tumor size was observed by Mohsin et al. ${ }^{10}$

\section{Hormone receptors and grade of the tumor}

Table 20: Correlation of Estrogen receptor (ER) and progesterone receptor (PR) positive status with different histological grades of IBC- NST by various authors

\begin{tabular}{|c|c|c|c|}
\hline \multirow[t]{2}{*}{ Authors } & \multicolumn{3}{|c|}{ IBC - NST } \\
\hline & Grade - I & Grade - II & Grade - III \\
\hline Present study & $\begin{array}{c}30 / 34 \\
(88.34 \%)\end{array}$ & $\begin{array}{c}26 / 36 \\
(72.22 \%)\end{array}$ & $\begin{array}{c}8 / 38 \\
(21.05 \%)\end{array}$ \\
\hline Dutta et al(2008) ${ }^{11}$ & $4 / 8(50 \%)$ & $\begin{array}{c}18 / 57 \\
(31.7 \%)\end{array}$ & $3 / 10(30 \%)$ \\
\hline $\begin{array}{l}\text { Geethamala } K \text { et } \\
\text { al }(2015)^{18}\end{array}$ & $\begin{array}{c}15 / 19 \\
(78.9 \%)\end{array}$ & $\begin{array}{c}35 / 54 \\
(64.9 \%) \\
\end{array}$ & $2 / 27(7.4 \%)$ \\
\hline $\begin{array}{lll}\begin{array}{l}\text { Gupta } \\
(2015)^{21}\end{array} & \text { et } & \text { al }\end{array}$ & $\begin{array}{l}10 / 12 \\
(83 \%)\end{array}$ & $5 / 23(22 \%)$ & $0 / 15(0 \%)$ \\
\hline Chua et al $(1985)^{19}$ & $5 / 6(83 \%)$ & $\begin{array}{l}19 / 24 \\
(79 \%)\end{array}$ & $6 / 15(40 \%)$ \\
\hline $\begin{array}{l}\text { Al-Nuaimy et al } \\
(\mathbf{2 0 1 5})^{23}\end{array}$ & $1 / 1(100 \%)$ & $\begin{array}{l}49 / 71 \\
(69 \%)\end{array}$ & $31 / 56(55 \%)$ \\
\hline
\end{tabular}

In the present study has high statistical significance $(p=0.0001)$ between IBC - NST grade and ER and PR status. This findings are similar 
with many of the previous studies. ${ }^{18,21,19,23}$ In the present study, ER and PR positivity decreased as the grade of the tumor increased.

\section{Hormone receptors and axillary lymph node metastasis}

Table 21: Correlation of estrogen receptor (ER) and progesterone receptor (PR) positive status with axillary lymph node metastasis by various authors

\begin{tabular}{|l|c|c|c|}
\hline Authors & $\begin{array}{c}\text { Axillary } \\
\text { LN 0 }\end{array}$ & $\begin{array}{c}\text { Axillary } \\
\text { LN 1-3 }\end{array}$ & $\begin{array}{c}\text { Axillary LN } \\
>3\end{array}$ \\
\hline $\begin{array}{l}\text { Present } \\
\text { study }\end{array}$ & $\begin{array}{c}26 / 40 \\
(65 \%)\end{array}$ & $\begin{array}{c}34 / 48 \\
(70.83 \%)\end{array}$ & $\begin{array}{c}2 / 22 \\
(9.09 \%)\end{array}$ \\
\hline $\begin{array}{l}\text { Chua et al } \\
(1985)^{19}\end{array}$ & $\begin{array}{c}15 / 22 \\
(68 \%)\end{array}$ & $\begin{array}{c}10 / 14 \\
(71 \%)\end{array}$ & $5 / 9(56 \%)$ \\
\hline $\begin{array}{l}\text { Al- Nuaimy } \\
\text { et al (2015) }\end{array}$ & $\begin{array}{l}\mathbf{2 3} / 34 \\
(68 \%)\end{array}$ & $\begin{array}{l}\mathbf{2 6} / 42 \\
(62 \%)\end{array}$ & $\mathbf{2 7 / 4 4 ( 6 1 \% )}$ \\
\hline
\end{tabular}

In the present study, decreasing ER and PR positivity is noted with increasing number of axillary lymph node metastases.

It was statistically significant ( $\mathrm{p}=0.0001)$.

Similar findings were observed by AlZaman et $\mathrm{al}^{25,}$ Chua et $\mathrm{al}^{19}$, Al- Nuaimy et $\mathrm{al}^{23}$

They found a strong correlation between ER and PR negativity and lymph node positivity. There was $31 \%$ of lymph node positive patients that were ER negative, compared with $13 \%$ of lymph node negative patients $(\mathrm{p}=0.06)$. Similarly, $35 \%$ of lymph node positive patients were PR negative compared with $10 \%$ of lymph node negative patients $(\mathrm{p}=0.01)$.

However, Almasri et al ${ }^{12}$ Gulam et al ${ }^{13}$ and Rao et $\mathrm{al}^{27}$ could not find any significant relationship between ER and PR level and the presence and absence of axillary lymph node metastasis.

Table 23: Histological types in comparison with other studies

\begin{tabular}{|l|c|c|c|}
\hline \multirow{2}{*}{ Histological types } & \multicolumn{3}{|c|}{ Authors } \\
\cline { 2 - 4 } & $\begin{array}{l}\text { Ontilo AA } \\
\text { et al }^{16}(\boldsymbol{\%})\end{array}$ & $\begin{array}{c}\text { Zafrani B et al } \\
(\mathbf{\%})\end{array}$ & $\begin{array}{c}\text { Present } \\
\text { study (\%) }\end{array}$ \\
\hline $\begin{array}{l}\text { Invasive breast } \\
\text { carcinoma (no } \\
\text { special type) }\end{array}$ & $72.7 \%$ & $77 \%$ & $78.18 \%$ \\
\hline Others & $23.3 \%$ & $23 \%$ & 21.82 \\
\hline
\end{tabular}

In the present study $78.18 \%$ were Invasive breast carcinoma-non specific type and $21.82 \%$ were other types.
Similar observation was made by Zafrani B et $\mathrm{al}^{17}$ and Onitilo $\mathrm{AA}^{16}$ et al. Other types of carcinomas had varied incidence in different studies.

\section{Therapeutic decision making ${ }^{20}$}

Was done based on the guidelines of Breast cancer treatment protocol: Health professional version (National cancer institute at National institute of health)

1. Patients would need only hormone therapy in cases of.

\section{Low Tumor Burden}

- Tumor size (T1 and T2)

- Grade of the tumor (grade1 and grade 2)

- Patients with less than 4 lymph nodes positive

\section{ER/PR positive status}

Pre-menopausal patients would benefit by ovarian ablation/Supression

\section{Patients would need both hormone therapy and chemotherapy in cases of \\ High Tumor Burden}

- Tumor size of T3

- Grade 3 and above

ER/PR positive status

3) Patients would benifit only by chemotherapy in cases of

- $\mathrm{T} 3$ tumors

- Grade 3 and above

Estrogens and progesterone receptor negative status

Table 24: Based on the above guidelines therapy required would be

\begin{tabular}{|l|c|c|}
\hline Therapy Required & Number & Percentage \\
\hline Hormonal Therapy & 56 & $50.90 \%$ \\
\hline Chemotherapy & 45 & $40.90 \%$ \\
\hline Hormonal+Chemotherapy & 9 & $8.18 \%$ \\
\hline Total & 110 & $100 \%$ \\
\hline
\end{tabular}

In our study based on the above guidelines our systemic therapeutic decision will be 56 patients $(50.90 \%)$ of patients would require hormone therapy

45 patients $(40.90 \%)$ of patients would require chemotherapy 
9 patients $(8.18 \%)$ of patients would require hormonal + chemotherapy

\section{Summary}

- This study is a prospective study conducted on 110 women with carcinoma breast done over a period from December 2016 to June 2018. Prognostic factors such as age, parity, menopausal status and histomorphological factors such as size of the tumor, tumor grade, histological type, axillary lymph node metastasis status was correlated with ER and PR status.

- Maximum numbers of patients included in the study were in the age group of $41-50$ years of life( $31.82 \%)$, our analysis showed that POSITIVE ER and PR status increases with age, the chi square test shows $p$ value of $<0.0001$ which is highly significant

- Most number of patients had a tumor size of $2-5 \mathrm{~cm}$, As the tumor size increases the NEGATIVE ER and PR status increases, the chi square test shows $p$ value of $<0.0001$ which is highly significant.

- As the number of positive axillary lymph nodes increased, ER/PR NEGATIVITY increased, chi square test shows a $p$ value of $<0.0001$ which is highly significant.

- As histological grade of the tumor was compare with ER and PR status which showed that well differentiated tumors (grade I) were mostly ER and PR POSTIVE while moderately and poorly differentiated (grade II,III) tumors were mostly ER/PR NEGATIVE tumors.

- The grade of tumor when compared with ER/PR status was more positive as the tumor became well differentiated. The $\mathrm{p}$ value on chi square test was found to be $<0.0001$ hence the study is highly significant.

- Menopausal status of the women when compared with ER and PR status is found to be mostly ER and PR POSITIVE in post menopausal women but the $\mathrm{p}$ value on chi square test is found to be 0.699 which is insignificant.

- Parity compared to ER and PR status is found to be more ER and PR negative as parity increases

- Staging of the patients is done and is found to have maximum number of patients with

- Most patients with Stage II (IIA $24.54 \%$, IIB 30.00\%), Stage IIIA $(27.27 \%)$ and least number of patients with stage I (IA-10.90\%, IB-7.27\%)

- Therapeutic decision making was done based on the

1) Staging 2) $E R$ and $P R$ status 3) Histological grade of the tumor

$50.90 \%$ patients would benefit from exclusive hormonal therapy, $40.90 \%$ patients needed a combination of hormonal and chemotherapy and $8.18 \%$ of patients would benefit only from chemotherapy.

\section{Conclusion}

Estrogen and Progesterone receptor status correlate well with the established prognostic markers like age of the patient, parity, tumor size, histological grade; axillary lymph node metastasis .and these factors help is selecting the patients for target therapy.

1) Patients with ER and PR receptor positive status have,

- Grade I (well differentiated), less aggressive tumors

- lower incidence of axillary lymph node metastasis

- smaller tumor size

- Post menopausal status

- lesser parity

2) Patients with ER and PR negative status have,

- Grade II and III (moderately to poorly differentiated), highly aggressive tumors 
- Higher incidence of axillary lymph node metastasis

- bigger tumor size

- pre-menopausal women

- higher parity

3) The status of ER and PR, Grade of tumor and stating helps with adjuvant therapy decision making.

- The women with ER and PR POSITIVE status with stage IA, IB, IA with grade I or II would benefit from HORMONAL THERAPY.

"Premenopausal women will need ovarian ablation

- The women with ER and PR POSITIVE status with stage IIB and IIIA and grade I or II would need a combination of HORMONAL

AND CHEMOTHERAPY.

- CHEMOTHERAPY alone will be beneficial in cases of ER and PR NEGATIVE and grade III patients.

\section{Bibliography}

1. Bhagat VM, Jha BM, Patel PR. Correlation of hormonal receptor and Her-2/neu expression in breast cancer : A study at tertiary care hospital in south Gujrat. National Journal of Medical Research. 2012; 2(3):295298.

2. Harrison AP, Srinivasan K, Binu VS, Vidyasagar MS, Nair S. Int J Collab Res Intern Med Public Health. 2010; 2(4):109116.

3. Leong SPL, Shen ZZ, Liu TJ, Agarwal G, Tajima T, Paik NS et al. Is breast cancer the same in disease in Asian and western countries?. World J Surg. 2010; 34:23082324.

4. Shrigondekar P, Desai S, Bhosale S, Mankar D, Badwe A. Study of hormone receptor status of breast carcinoma and its correlation with the established prognostic markers. I J H S R. 2012; 1(2):109-116.

5. Hoda SA. Invasive ductal carcinoma: Assessment of prognosis with morphologic and biologic markers. In: Hoda SA, Brogi E, Koerner FC, Rosen PP, editors. Rosen's Breast Pathology. $4^{\text {th }}$ ed. Philadelphia: Lippincott Williams \& Wilkins; 2014: 413 456.

6. Biganzoli L. Prognostic and predictive factors. In: Castiglione M, Piccart M editor. Adjuvant Therapy for Breast Cancer. Cancer Treatment and Research, vol 151. Boston: Springer; 2009: 13-30.

7. Dowsett M, Miller W. Estrogen and progesterone receptor testing for prognosis and prediction . In: Harris JR, Lippman ME, Morrow M, Osborne CK . Disease of the breast. $5^{\text {th }}$ ed. Philadelphia: Wolters Kluwer ; 2014: 411- 421.

8. Faheem M, Mahmood H, Khurram M, Qasim U, Irfan J. Estrogen receptor, progesterone receptor, and $\mathrm{Her} 2 \mathrm{Neu}$ positivity and it's association with tumor characteristics and menopausal status in a breast cancer cohort from northern Pakistan. eCancer. 2012 ; 6(283):1-8.

9. De SK, PS, Pruthvi, GU K, Nandyal SN, H SJ. Estrogen, progesterone and human epidermal growth factor receptor-2 in malignant breast lesions : A 5 year study in a tertiary care hospital of Karnataka. Indian Journal of Pathology and Oncology. 2015; 2(4):230-235.

10. Mohsin SK, Weiss H, Havighurst T, Clark GM, Berardo M, Roanh LD et al. Progesterone receptor by immunohistochemistry and clinical outcome in breast cancer: a validation study. Modern Pathology. 2004 ;17:1545-1554.

11. Dutta V, Chopra GS, Sahai K, Nema SK. Hormone receptors, Her $2 / n e u$ and chromosomal aberrations in breast cancer. M J A F I. 2008; 64:11-15.

12. Almasri NM, Hamad MA. Immunohistochemical evaluation of human epidermal growth factor receptor 2 and estrogen and progesterone receptors in 
breast carcinoma in Jordon. Breast Cancer Res. 2005 ; 7(5) : 598-604.

13. GulamNS , Junaid NS, Raja N, Rayees YS , Faroze AK, Abid AS et al. Estrogen receptor and progesterone receptor status in breast cancer in relation to age, histological grade, size of lesion and lymph nodeinvolvement. Asian Pacific J Cancer Prev. 2012;13(10):50475052.

14. Donegan WL. Prognostic factors: Stage and receptor status in breast cancer. Cancer. 1992 ;70:1755-1764.

15. Reiner A, Reiner G, Spona J, Schemper M, Holzner JH. Histopathologic characterization of human breast cancer in correlation with estrogenreveptor status. Cancer. 1988; 61:1149-1154.

16. Zafrani B, Aubriot M, Cremoux P, Rycke Y, Nicolas A, Boudou E et al. High sensitivity and specifying of immunohistochemistry for the detection of hormone receptors in breast carcinoma: comparison with biochemical determination in a prospective study of 793 cases. Hisopathology2000;37:536-45.

17. Onitilo AA, Engel MJ, Greenlee TR, Mukesh NB. Breast Cancer subtypes based on ER/PR and HER-2 expression : Comparison of Clinicopathologic features and survival. Clinical Medicine and Research ;7(1/2):4-13

18. Geethamala K, Murthy VS, Vani BR, Rao S. Histopathological grade versus hormone receptor status in breast carcinoma treasure the past. I J B R. 2015; 6(07):466471

19. Chua DYF, Pang MWY, Rauf A, AWS, Chan S. Correlation of steroid receptors with histologic differentiation in mammary carcinoma: A Singapore experience. Cancer. 1985; 56:2228-2234.

20. Senkus E, Kyriakides S, Penault-Llorca F, et al.: Primary breast cancer: ESMO Clinical
Practice Guidelines for diagnosis, treatment and follow-up. Ann Oncol 24 (Suppl 6): vi7-23, 2013.

21. Gupta D, Gupta V, Marwah N, Gill M, Gupta S, Gupta G et al. Correlation of hormone receptor expression with histologic parameters in benign and malignant breast tumors. Iran J Pathol. 2015; 10(1):23-34.

22. Edge SB, Byrd DR, Compton CC, et al., eds.: AJCC Cancer Staging Manual. 7th ed. New York, NY: Springer, 2010, pp 347-76.

23. Al-Nuaimy WMT, Ahmed AH, Al-Nuaimy HAA. Immunohistochemical evaluation of triple markers (ER, PR and HER-2/neu) in carcinoma of the breast in the north of Iraq. Donn J Med lab Diagn. 2015;1(1):52-60.

24. Taucher S, Rudas M, Madar RM, Gnant M, Dubsky P, BachleitnerT,et al. Do we need HER-2/neu testing for all patients with primary breast carcinoma? Cancer. 2003; 98(12):2547-2553.

25. Al Zaman AS, Mughal SA, Al Zaman YS, Al Zaman ES. Correlation between hormone receptor status and age, and its prognostic implications in breast cancer patients in Bahrain. Saudi Med J. 2016; 37(1):37-42.

26. Nomura Y, Miura S, Koyama H, Enomoto $\mathrm{K}$, Kasumi F, Yamamoto $\mathrm{H}$ et al. Relative effect of steroid hormone receptors on the prognosis of patients with operable breast cancer: A univariate and multivariate analysis of 3089 Japanese patients with breast cancer from the study group for the Japanese breast cancer society on hormone receptors and prognosis in breast cancer. Cancer. 1992; 69(1):153-164.

27. Rao C, Shetty J, Prasad KH. Morphological profile and receptor status in breast carcinoma: An institutional study. J Cancer Res Ther. 2013; 9(1):44-49. 